Policy Research Working Paper

\title{
The Significance of Credits and Subsidies in Russian Agricultural Reform
}

\author{
Douglas Galbi
}

The World Bank

Office of the Vice President

Development Economics

March 1995

WPS 1441

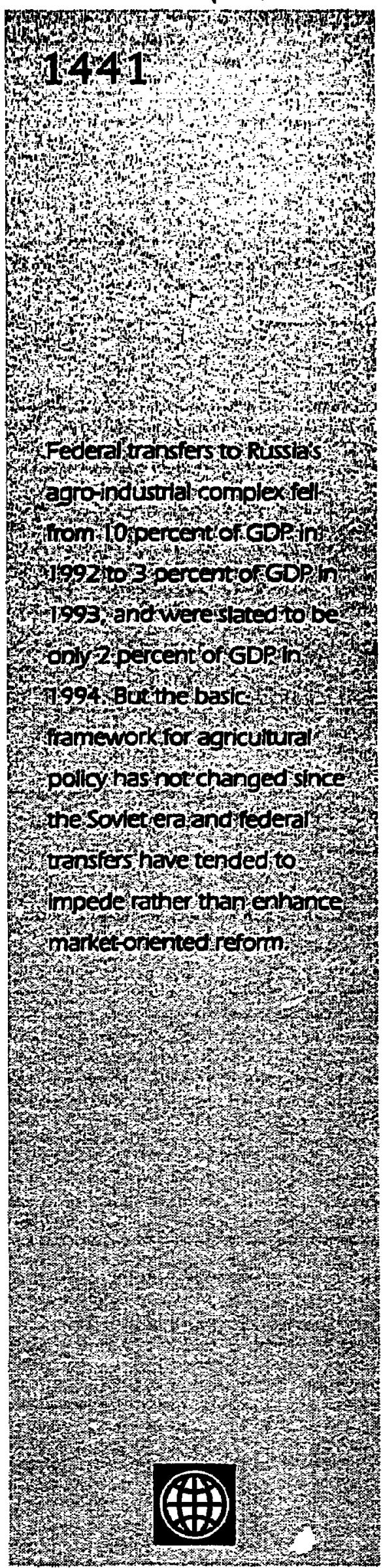




\section{Summary findings}

Galbi analyzes the role of federal agricultural credits and subsidies in Russia since the Gaidar reforms of January 1992.

Pressure on the budget has led to a significant reduction in federal transfers to the agro-industrial complex. Transfers fell from 10 percent of gross domestic product (GDP) in 1992 to 3 percent of GDP in 1993, and budget transfers for 1994 are only about 2 percent of GDP.

But the nature of federal transfers to the agroindustrial complex has not changed significantly since 1992, and federal transfers have tended to impede market-oriented reform rather than enhance it. So reform in the agriculture sector has been driven largely by a budget squeeze on the implementation of policies that hinder the development of market-oriented agriculture.
Galbi provides an overview of federal agro-industrial programs, describing four types of support in detail:

- Credits and subsidies to promote private farms.

- Credits associated with state procurement of agricultural products.

- Subsidies for agricultural inputs.

- r eneral subsidies to agricultural producers.

He shows the difficulty of using federal transfers to support agriculture when institutions are unstable, the government's administrative and regulatory capabilities are weak, and information needed for effective credit allocation is unavailable.

He also shows the extent to which the framework for agricultural policy has not changed since the Soviet era.

This paper - 2 product of the Office of the Vice President, Development Economics - is part of an ongoing research on Russian monetary and credit policy. Copies of the paper are available free from the World Bank, 1818 H Street NW, Washington, DC 20433. Please contact Nen Castillo, room S9-035, extension 33490 (37 pages). March 1995.

The Policy Research Working Paper Saries disseminates the findings of work in progress to encounage the exchange of ideas about development issues. An objective of the series is to get the findinges out quickly, even if the presentations are less than fully polished. The papers carn the names of the authors and sbould be used and cited accordingly. The findings, interpretations, and conclusions are the authors' oum and should not be attributed to the World Bank, its Executive Board of Directors, or any of its menber conntries. 


\title{
The Significance of Credits and Subsidies in Russian Agricultural Reform
}

\author{
Douglas Galbi
}

Consultant

The World Bank

DECVP

This paper was written under Paulo Vieira da Cunha, DECVP, as part of ongoing research on Russian monetary and credit policy. It benefited greatly from Lev Freinkman's work on federal financial transfers and local budgets in Russia, as well as his additional suggestions and insights. I am also grateful for comments from Karen Brooks, Qimiao Fan, Tim Heleniak, Vincent Koen, Vera A. Matusevich, Olga Shabalina, Anning Wei, and Dennis Whittle. The Common Security Forum, an international project examing post-Cold-War conceptions of security, provided funding for part of the research on which this paper is based. 
This paper will describe and analyze the role of federal agricultural credits and subsidies in Russia since the Gaidar reforms of January 1992. There are two key points. First, pressure on the budget has led to a significant reduction in total federal transfers to the agro-industrial complex. Federal transfers to the agro-industrial complex fell from 10\% of GDP in 1992 to $3 \%$ of GDP in 1993, and budgeted transfers in 1994 are about $2 \%$ of GLP. Second, the nature of federal transfers to the agro-industrial complex has not changed significantly since 1992 , and federal transfers have tended to impede market-oriented reform rather than enhance it. Thus reform in the agricultural sector has been driven forward largely by a budgetary squeeze on the implementation of policies that hinder the development of market-oriented agriculture.

The organization of this paper is as follows. The first section will provide an overview of federal agro-industrial programs, while four subsequent sections will examine broad categories of support in more detail. These categories are credits and subsidies to promote private farms, credits associated with state procurement of agricultural products, subsidies for agricultural inputs, and general agricultural producer subsidies. Developments in these areas show the difficulty of using federal transfers to support agriculture when institutions are unstable, the administrative and regulatory capacity of the government is weak, and information necessary for effective credit allocation is unavailable. Developments also show the extent to which the framework for agricultural policy has not changed since the Soviet era. 


\section{Federal Programs for the Agro-Industrial Complex}

As a category in Soviet economic planning, the agro-industrial complex included the suppliers of agricultural inputs and services, producers of agricultural goods, and organizations for processing and distributing agricultural products. The transition to markets is blurring the boundaries and structure of the agro-industrial complex. As part of the conversion effort, defense plants were encouraged to take up production of agricultural inputs, while agricultural banks are shifting into financing non-food trade. Nonetheless, the agro-industrial complex remains a central category in the Russian budgetary process.

The agro-industrial complex traditionally ranked with the military-industrial complex as having top priority in the allocation of state resources. Three important budgetary categnries of state support for the agro-industrial complex are input cost subsidies for agricultural producers, procurement credits and subsidies and general agricultural producer subsidies (including investment funds and support for social infrastructure). Table 1 shows the evolution of these categories of support. These aggregate figures make no distinction between credits and subsidies. However, for the agricultural sector the importance of the distinction between credits and subsidies is greatly reduced by chronic default in the repayment of state credit and highly negative real interest rates produced by low nominal interest rates and high inflation.' 
Table 1. Federal Transfers to the Agro-Industrial Complex (as \% of GDP)

\begin{tabular}{|l|c|c|c|}
\hline category & 1992 & 1993 & 1994 budgeted \\
\hline private farmers & 0.74 & 0.19 & 0.02 \\
\hline input cost subsidies & 0.83 & 0.08 & 0.13 \\
\hline $\begin{array}{l}\text { procurement } \\
\text { credits/subsidies }\end{array}$ & 4.47 & 1.57 & 0.87 \\
\hline $\begin{array}{l}\text { general producer } \\
\text { credit/subsidies }\end{array}$ & 4.05 & 1.33 & 0.94 \\
\hline total & 10.09 & 3.17 & 1.96 \\
\hline
\end{tabular}

Source: Freinkman (1994) and Budget RF (1994). The nominal figures for Input subsidles, procurement subsidies, and generil producer subsidies were (in bln. Rb) 1992: 809, 151, 791; 1993: 2540, 113, 2446; 1994: 6400, 1802, 6126. The nominal GDP

figures for 1992-4 are respectively 18. I, 162, and $\mathbf{2 3}$ trl. Rb. These figures exclude interest rate subsidies, tax exemptions, and centralized impons of ag. inputs, as well as general subsidies for producers of agricultural inpuls. The 1994 proetrement credits include Rb $1.8 \mathrm{trl}$. to cover purchases of grain from the 1993 harvest.

Several important points are apparent from Table 1. First, the over-all volume of federal transfers to the agro-industrial complex has been reduced by more than a factor of four since 1992. While the 1992 and 1993 figures represent actual disbursements, the 1994 figures are from the budget passed in June 1994. Additional commitments have been made outside the budget, and an Izvestiya investigation into agricultural finance reported total commitments for 1994 as equal to $2.9 \%$ of GDP. ${ }^{2}$ However, as in the previous two years, disbursements have fallen significantly below budgetary commitments, and the same source gives disbursements through November 1994 as $1.3 \%$ of GDP. ${ }^{3}$ In any case there is a clear downward trend in total disbursements to the agro-industrial complex.

There has been little change, however, in the structure of agricultural programs. Funds for state procurement and general subsidies for agricultural are the most important categories of support and are roughly equal in size. Grain credits dominate the procurement transfers while general support for producers seems to consist largely of ad-hoc subsidies. In 1994 one new 
program of support for agriculture was introduced: funds amounting to about a twelfth of total support for agriculture were allocated to setting up a fund of equipment that could be rented to food processors. However, this program was not carried out and no funds were disbursed. Funding for agricultural research has continued at a relatively high level. Budgeted funding for agricultural research in 1994 amounted to about $\$ 127$ million, an amount equal to $61 \%$ of the amount of federal funding assigned to the Russian Academy of Science, including the Ural and Siberian sections.

\section{Promoting Private Farming}

While personal subsidiary plots have long played a key role in Russian agriculture, legislation enabling independent private farms was enacted only in December of $1990 .{ }^{5}$ This legislation provided three means for the formation of private farms. One is that a member of a collective or state farm could claim his or her share of land and equipment from the collective and exit to form a small farm. State and collective farms were also required to turn over of portion of their "underutilized" land to the local Soviet. This land is to be distributed to other persons who want to become farmers. Persons who want to become farmers can also buy land from the state or lease it from other owners.

In addition to providing enabling legislation, the Russian government also provided subsidies for private farmers. In the spring of 1991 the Russian government provided a billion rubles (about $\$ 38$ million at the average 1991 exchange rate) to the newly formed Association of 
Peasant Farms and Cooperatives (AKKOR). The justification for the budgetary allocation was to promote the development of independent private farms. These funds were used in part to build up AKKOR, which set up a central office in Moscow and affiliates in all the regions of Russia. Budgetary funds and credits were also distributed to the regional affiliates based on their number of farmers and acreage that that farmers held. The governing committees of the local affiliates made the ultimate decisions about the allocation of local subsidies and credits. ${ }^{6}$

The amount of resources that the government provided to new independent private farmers in 1991 and 1992 was relatively large. As Table 2 shows, transfers to support private farming in 1991, relative to the number of independent private farmers active in mid-1991, amounted to about two huncired and twenty times the average monthly industrial wage. In 1992 the level of support fell slightly while the mix of support shifted more towards directed credits. These credits were issued at $8 \%$ interest per year. About $60 \%$ of the credit was one-year credit and $40 \%$ was five-year credit. ${ }^{7}$ In light of the very high inflation rates $(1800 \%$ in 1992$)$, these credits were virtually equivalent to a subsidy.

After 1992 the overall volume of state support for private farmers dropped sharply, falling from one hundred and seventy-five times the average monthly industrial wage in 1992 to twenty times the monthly wage in 1993 . Within the overall lower volume of support, the importance of directed credits increased sharply. However, in the fall of 1993 moves were taken to eliminate directed credits. While directed credit figures for 1994 are not available, the magnitude of such credits is probably small. Overall, the volume of support for private famers continued to drop sharply, falling in real terms by about a factor of ten. 
Table 2. State Support for Private Farms

\begin{tabular}{|c|c|c|c|c|}
\hline year & $\begin{array}{c}\text { \# of farms } \\
\text { (ths.) }\end{array}$ & $\begin{array}{c}\text { budgetary } \\
\text { subsidy (bln. } \\
\mathrm{Rb} \text { ) }\end{array}$ & $\begin{array}{c}\text { central credit } \\
\text { (bln. Rb) }\end{array}$ & $\begin{array}{c}\text { total transfer relative } \\
\text { to monthly ind. wage }\end{array}$ \\
\hline 1991 & 25 & 1.7 & 1.3 & 219 \\
\hline 1992 & 129 & 55 & 79 & 175 \\
\hline 1993 & 258 & 22 & 288 & 20 \\
\hline 1994 & 286 & 127 & (small) & 2 \\
\hline
\end{tabular}

Notes and sources: The number of tarms is a mld-year (1 July) tigure from Kisclev (1994), Goskomstar (1994a) p. 3, (1994b) p. 47. Budge'ry subsidles are from personal communication. Freinkman (1994), and Budget RF (1994). The budget figure for 1994 has been multiplied by .5l, the implementation factor from 1993. Izvestiya(1994) gave a figure of Rb $112.2 \mathrm{bln}$. Central eredit figures are from Kisclev (1994) p. 78, and persons' communication from the Russian Farmers' Fund, where the 1993 figure has been sealed up from a year-lo-date figure for 20 Sepl. 1993.

The possi vility of receiving state su:pport probably played a key role in the rapid growth of private farms. From mid-1991 to mid-1992 the number of private farms increased by a factor of five, and then doubled from mid-1992 to mid-1993 to reach 258 thousand. Some of the farmers who began in 1991 drew upon their own savings, while in January 1992 the savings of the population were largely wiped out by inflation. By the end of 1992 credit appears as a major item in the operating balance of the new private farmers, amounting to $180 \%$ of gross revenues. Other evidence suggests that $43 \%$ of independent private farmers in 1992 received no credit at all.' This suggests that the credit to revenue ratio was significantly higher for those who actually did receive credit. Thus receiving or not receiving state credit was an enormously significant factor for a farmer's financial position.

The issue of who would be provided with start-up capital, and how state support would be divided between setting up new private farms and supporting already established independent private farms, was never openly addressed. ${ }^{10}$ This is not surprising, since such a question would focus on the allocation of capital within AKKOR, and hence be divisive. A typical way of 
avoiding the issue wras to treat it as an issue of technical experise. As one Russian academic put it with respect to land distribution, "...not everyone has the right to land, but only the best of the best, those who are experienced and who are trained professionais." "I While the rights of members of states or collective farms to receive land is defined in statutes, and does not include expertise or training as criteria, the allocation of land to immigrants from towns or the army is significantly affected by such notions of expertise. ${ }^{12}$ These notions tend to ignore the issue of who decides who is skilled and appropriately trained. Moreover, an independent farmer is first and foremost a small business person. A major problem of post-comminist economic transformation is that under communism small business was systematically and effectively repressed. It is not possible or desirable to use the past to try to identify who will be successful in a future that must be much different from the past.

The information necessary for effective resource allocation emerges only over time with the success and failure of individual farmers. Since information on the performance and credit worthiness of the new farmers was initially lacking, effective credit institutions would have provided small amounts of credit and built upon accumulated performance information to expand credit to successful private farmers. More pressure for self-financing would have helped to insure that farmers who were able to generate cash-flow from farming were the ones who expanded.

The policy followed, which issued large lump sum disbursements of credit through a murky political process, is not likely to promote the development of efficient private farmers. While systematic evidence is not available, anecdotal evidence suggests that the default rate on state credits to private farmers has been high. When the level of state support for private farmers 
fell in 1993, the growth rate of private farms slowed dramatically and the failure rate increased (see Tables 2 and 3). Morcover, grain yields on private farms have turned out to be $18 \%$ lower than on state and collective farms, which themselves are widely recognized us being woefully inefficient. $^{13}$

Table 3. Farm Failure Rates

\begin{tabular}{|l|c|c|}
\hline period & \# of failed farms in period & $\%$ of active (end of period) \\
\hline 1992 & 5118 & 2.8 \\
\hline I'st half, 1993 & 5800 & 2.2 \\
\hline 2'nd half, 1993 & 8300 & 3.1 \\
\hline I'st half, 1994 & 12100 & 6.6 \\
\hline
\end{tabular}

Source: Goskomstat (1994a) pp. 3-5, (19946) pp 47-8.

There is, however, at least one potentially promising sign. While the total volume of agricultural credit fell in real terms by about two-thirds from 1992 to 1993, a larger share of credit appears to have been mobilized privately. In 1992 the average volume of credit that private farmers received was $67 \%$ of the volume of directed state credits for private farmers, while in 1993 this figure rose to $134 \% .^{14}$ This shift suggests that private rural credit markets are developing. ${ }^{15}$ One would expect such markets to provide short-term credits, and in fact the share of short-term credits in the credit that private farmers received rose from $27 \%$ in 1992 to $53 \%$ in 1993. ${ }^{16}$ Private creditors who want to be repaid have a good incentive to lend only to farmers who they know are efficient. On the other hand, private lending may also be seeking out poor farmers with valuable land that might be seized in the likely event of default on the loan.

The attempt to create private farmers through state credits and subsidies turned out to be a costly and ineffective way to promote agricultural reform. The large transfers obscured market forces that would select and reward private farmers for their performance in farming. The 
attempt created a new central bureaucracy, AKKOR. While AKKOR has important tunctions to serve in providing techuical assistance and disseminating information, its existence largely depends on its ability to lobby the government for credits and subsidies. In order for AKKOR to gain bargaining power, it has to provide support for other state bureaucracies. Thus in early 1992 the AKKOR leadership agreed with the Russian government that peasant farmers would deliver $25 \%$ of their products to state procurement agencies at market prices in order to receive support channeled through AKKOR. While the enforceability or even the meaning of such an agreement is questionable, it illustrates the extent to which policy toward private farms fell within the traditional planning framework. ${ }^{18}$

\section{Procurement Credit and the Marketing of Agricultural Products}

While the volume of state procurement has fallen significantly since the late 1980 's, the state still purchases a significant share of major agricultural products. In 1993 about $50 \%$ of livestock products were purchased through state procurement, while the figure for plant products was about $25 \%$. See Table 4. Production that the state did not procure includes product that spoiled or rotted (thought to amount to $20-30 \%$ of production), product consumed on farm, product sold or bartered directly from the farm, and product sold to private distributors. The total cost of products that the state procured in 1993 amounted to $3.7 \%$ of 1993 GDP. 
Table 4. The Significance of State Procurement

\begin{tabular}{|l|c|c|c|c|}
\hline product & $\begin{array}{l}\text { procurement as } \\
\% \text { of prod'n, } \\
\text { ave. 1986-90 }\end{array}$ & $\begin{array}{l}\text { procurement as } \\
\% \text { of prod'n, } \\
1993\end{array}$ & $\begin{array}{l}\text { total volume of } \\
\text { procurement } \\
1993, \text { ths. tons }\end{array}$ & $\begin{array}{l}\text { total cost of } \\
\text { procurement } \\
1993, \text { bil. Rub. }\end{array}$ \\
\hline milk & 72.1 & 52.4 & 24632 & 1188 \\
\hline meat & 74.5 & 49.4 & 5273 & 1886 \\
\hline eggs & 70.9 & 60.0 & 22789 & 476 \\
\hline grain & 32.9 & 27.7 & 27968 & 1801 \\
\hline potatoes & 22.4 & 4.4 & 1670 & 112 \\
\hline vegetables & 66.5 & 21.7 & 2122 & 315 \\
\hline sugar beets & 86.7 & 27.7 & 7064 & 176 \\
\hline sunflower & 76.1 & 23.0 & 645 & 59 \\
\hline
\end{tabular}

Source: Calculated from Ministry of Agriculture (1994a,b).

State procurement is used in part to fill federal and regional food funds. The melange of recipients of products from the federal food fund illustrates the persistence of traditional forms of resource allocation. For example, in 1993 the federal food fund was ordered to deliver 1.8 thousand tons of milk to the Russian meteorological service, 7.2 thousand tons of meat to the tax service, and 65 million eggs to the joint stock company Gasprom, among other recipients. As Table 5 illustrates, government organs of various sorts are very significant customers of the federal and regional food funds. 
Table 5. Allocation of Food from Federal and Regional Food Funds in 1993 (ths. tons)

\begin{tabular}{|l|l|l|l|l|l|l|}
\hline recipient & meat & milk & eggs & grain & sugar & vegetables \\
\hline Moscow & 550 & 4000 & 1430 & 1350 & 554 & 390 \\
\hline St. Petersburg & 150 & 1400 & 800 & 700 & 270 & 190 \\
\hline military & 492 & 2408 & 1362 & 1887 & 205 & 417 \\
\hline government organs & 120 & 1530 & 374 & 2423 & 764 & 4 \\
\hline enterprises & 57 & 436 & 358 & 0 & 329 & 16 \\
\hline regions & 179 & 1489 & 94 & 17665 & 1368 & 209 \\
\hline others & 21 & 600 & 1290 & 3613 & 398 & 0 \\
\hline $\begin{array}{l}\text { total allocation } \\
\text { from fed. and } \\
\text { reg'n food funds }\end{array}$ & 1570 & 11863 & 5709 & 27638 & 3888 & 1235 \\
\hline $\begin{array}{l}\text { planned size of } \\
\text { fed. food fund }\end{array}$ & 983 & 6042 & 5833 & 11828 & 784 & 1245 \\
\hline $\begin{array}{l}\text { residual (reg'n } \\
\text { food fund, waste) }\end{array}$ & 587 & 5821 & -124 & 15810 & 3104 & -10 \\
\hline
\end{tabular}

The 1994 legislation concerning state procurement gives some indication of less topdown control over procurement. ${ }^{19}$ In place of the detailed allocations set out in 1993, the 1994 legislation merely indicates that the federal food fund is to provide for the needs of the military and equivalent consumers, the Far North and equivalent locations, and in part Moscow and St. Petersburg. In addition, the Trade Committee of the Russian Federation is assigned the task of setting up government reserves of meat and meat products, milk and milk products, sugar, vegetable oil, and fish and fish conserves. Regional food funds are supposed to be formed by local governments with funds that they independently secure.

While in the 1994 federal food procurement legislation there is less emphasis on detailed allocations, there are some dramatic changes in the composition of the federal food fund. Federal procurement plans for meat and sugar are $30 \%$ and $80 \%$ higher than ${ }^{\circ}$ ist year, while procurement 
targets for eggs and vegetables are $51 \%$ and $32 \%$ lower. These changes are much too large to be driven by changes in consumption; they may instead reflect shifts in bargaining power and a preference for higher value food products.

State subsidies and credits are directly related to the pattern of state procurement shares across products and over time in Table 4. Milk, meat, and eggs are products for which state procurement takes up the largest shares of production. As Section V discusses, these products have received the bulk of product-oriented production subsidies. Such subsidies naturally orient producers toward state marketing channels. Grain has seen the smallest drop.in the share of state procurement. As Table 6 indicates, procurement credits for grain make up the bulk of procurement credits. Potatoes, on the other hand, are a subsistence product largely grown in subsidiary plots, and have attracted relatively little state support.

Table 6. Directed Credits for Agricultural Procurement (bln. Rb)

\begin{tabular}{|l|l|l|l|}
\hline year & 1992 & 1993 & 1994 budgeted \\
\hline grain & 641 & 1956 & $\mathrm{n} / \mathrm{a}$ \\
\hline vegetables & 128 & 229 & $\mathrm{n} / \mathrm{a}$ \\
\hline rural retailers & 41 & 90 & $\mathrm{n} / \mathrm{a}$ \\
\hline other & 0 & 165 & $\mathrm{n} / \mathrm{a}$ \\
\hline total & 809 & 2470 & 5400 \\
\hline as \% of GDP & 4.5 & 1.6 & 1.0 \\
\hline
\end{tabular}

Source: Freinkman (1994). Table 2, and Budget RF (1994). The 1994 figure includes Rb $1.8 \mathrm{tln}$. issued to cover debts for product procured in 1993. See Lvestija (1994).

There is a sharp contrast between the use of state procurement credit for grain and vegetables and the absence of procurement credit for livestock products. It does not appear to be the case that procurement credits for livestock products are provided through regional budgets. ${ }^{20}$ The need for credit does not appear to be associated with the process of regional redistribution of food, since the patterns for grain and vegetables are much different. Almost half of state 
procurement of vegetables is used to provision Moscow and St. Petersburg, while there are no regional vegetable funds. In contrast, the total volume of grain in regional grain funds is about a third larger than the volume of grain in the federal fund, and regional grain transfers are large relative to total state deliveries of grain.

While grain procurement credit amounts to $80 \%$ of total state procurement credit, the cost of procuring grain is not a convincing rationale for issuing state credit for that purpose. The total cost of state purchases of other commodities, such as meat and milk, is about the same as the cost of state purchases of grain (see Table 4). Since most grain is harvested during August and September, there is significant seasonality associated with grain production. However, there is also significant seasonality associated with milk; in early summer milk production is about 2.5 times greater than in the winter. ${ }^{21}$ Moreover, grain is an alternative to rubles as a store of value and it may provide a less risky form of wealth than rubles in the current environment of macroeconomic uncertainty. With the development and privatization of storage facilities, producers will not rush to sell their grain immediately, and the government does not need to rush to provide credit so that it all can be bought immediately.

While even in a comparative sense the case for state procurement credits seems weak, the amount of resources involved is large. In 1992 federal credits for state procurement were of an amount equal to $4.5 \%$ of GDP. Federal procurement credits in 1993 fell to an amount equal to $1.6 \%$ of GDP, and the 1994 budgeted level is equivalent to $1.0 \%$ of GDP. See Table 6. While funds for state procurement have been falling, federal credit for the creation of food funds remains the largest item under agriculture in the 1994 federal budget. 
The 1994 budget explicitly notes that budgetary funds for procurement are issued "on the basis that they are to be returned." Given inflation rates on the order of $10 \%$ a month, simply returning this money after six months or a year (a typical term for procurement credits) implies a significant real transfer to the recipients and loss for the budget. Moreover, credits provided for procurement in the past have not been repaid, as the special remark in the budget hints. In 1992, about two-thirds of grain procurement credits were not returned on time, and in 1993 more grain procurement credits were rescheduled. In $199341 \%$ of all credits issued for the agricultural sector were rescheduled. ${ }^{22}$

Private agricultural marketing and distribution companies face large disadvantages in competing with state procurement agencies. A typical argument for the necessity of state procurement is that there are no other firms to take up the job. But private firms will not develop rapidly given the large volume of state procurement and special credit lines for state procurement agencies. Private firms trading in grain and vegetables have to borrow working capital at commercial interest rates, and hence face large disadvantages in competing with state agencies trading on highly subsidized state credits. Moreover, state procurement agencies' shipments to government organs can be used to offset the state credits they have already received. Thus payment is assured, a crucial competitive advantage in an environment where contracts are difficult to enforce and there is a large outstanding stock of inter-enterprise arrears.

Russian history provides some indication of the possible significance of private provision of grain procurement credit. Before the Bolshevik Revolution, the State Bank provided only $11 \%$ of credit for grain procurement and distribution, while state railroads provided another $6 \%$. Most state credit was directed to marginal markets in outlying areas. Private traders supplied 
credit in major markets, and they supplied $83 \%$ of credit overall. ${ }^{23}$ This is not surprising. Credit associated with grain wholesaling is a relatively simple form of short-term credit that does not require a sophisticated financial system. Such credit is often provided between private buyers and sellers as part of terms of sale, and such arrangements contribute to the development of more sophisticated financial institutions.

\section{The Administration of Grain Credits}

In order to better understand the effectiveness and cost of state procurement, it is worth examining in detail grain procurement credits, which amount to about $80 \%$ of total state procurement credits. Federal procurenent of grain is carried out by Roskhleb, a joint-stock company. ${ }^{24}$ By decree the price of grain is determined by negotiations among the Ministry of Agriculture, Roskhleb, the Ministry of Finance, the Price Committee, plenipotentiaries of the Agrarian Union, AKKOR, and other organizations representing the interests of producers and consumers. In recent years the Prime Minister has played a leading role in price negotiations. In a market economy, only the purchaser of grain would be concerned about the price of grain. In this case the price of grain involves negotiations at the highest level of government because the government has a large stake in the process through its provision of subsidized credit.

A key issue in the centralized price negotiations has been parity with the world price for grain. However, such parity is not appropriate given the centralized price setting mechanism and the weak private links between the Russian and world grain markets. ${ }^{25}$ The domestic grain supply curve facing the government is significantly more inelastic than would be the case for small buyers in a large market. If the government wants to buy a larger amount of grain, it has to 
pay a higher price. This is less true in the international market, since it is larger and more competitive. Thus a cost-minimizing procurement program, if it involved international and domestic purchases of grain, would imply a higher price for internationally purchased grain than for domestic grain. ${ }^{26}$

Centralized price setting for grain inevitably leads to struggles over quantities, since prices are not allowed to clear the market. In particular, it is difficult to predict the amount of grain that will actually be procured, since that depends on how the fixed price relates to evolving conditions in the market. In the past the government has reacted by turning to imports to make up for procurement shortfalls. One implication of the price-setting process is that fluctuations in grain imports may have little relation to the overall fluctuations in the size of the harvest. A regression of the logarithm of grain imports in the USSR from 1963 to 1991 gives the following results:

$$
\mathrm{LGI}_{\mathrm{t}}=.18+.36 \mathrm{LGI}_{\mathrm{t}-1}+.063 \mathrm{TR}_{\mathrm{t}}+.20 \mathrm{LHR}_{\mathrm{t}} \mathrm{r}^{2}=.60, \sigma=.71, \mathrm{DW}=2.0
$$

where LGI is the logarithm of grain imports, TR is a time trend, and LHR is the size of the harvest (standard errors are in parenthesis under the coefficients). The large standard error on the coefficient of LHR means that there is considerable volatility in grain imports that variations in the size of the harvest cannot explain. Such variations in imports are consistent with the implications of a centralized process of state procurement: the government has purchased grain internationally to make up for domestic procurement shortfalls rather than domestic production shortfalls. ${ }^{27}$ 


\section{The Regional Distribution of Grain Credits}

While the logic of markets and competition indicates that state grain procurement credits suppress and distort the development of wholesale and distribution facilities, perhaps the most serious flaw in the current system of state grain credits is the lack of supervision and accountability. ${ }^{28}$ In 1992 Roskhleb procured 26 million tons of grain at an average price of $\mathbf{R b}$ 12000 per ton. Under the grain procurement program, $\mathrm{Rb} 620$ billion of credit (equivalent to $3.5 \%$ of 1992 GDP) was issued to Roskhleb. This volume of credit amounts to about Rb 24000 per ton of grain procured, i.e., about twice the average price of grain. Thus at least half of the grain credits must have been used for purposes other than to pay producers of grain.

There are considerable regional disparities in the distribution of grain credits. Moscow City, for example, received $\mathbf{R b} 16.8$ billion in grain credits while St. Petersburg received $\mathbf{R b} 1.8$ billion. All of these credits apparently went for grain distribution and processing, yet it is hard to understand why Moscow, with a population $80 \%$ larger than St. Petersburg, needed over 9 times as much credit for these purposes. There are also significant variations in credit volumes in regions where grain was procured. In Orlovskia and Riazonskiai Oblasts the amount of grain credit per ton of grain procured was $\mathrm{Rb} 11000$ and $\mathrm{Rb} 14000$ respectively. In contrast, Tul'skaia Oblast, which is geographically located between them, received $R b 26000$ per ton of grain procured. Sverdlovskaia Oblast provides an extreme example. It received Rb 23 billion in grain credits while only 5.2 thousand tons of grain were procured in the oblast. Thus Sverdlovskaia Oblast received over $\mathrm{Rb} 4$ million per ton of grain procured. 
Part of grain credits issued in 1.992 went for grain-processing industries. Bread-making is by far the most important such industry. Another part of grain credits went for grain procurement and distribution. Inter-regional shipments of grain compensate for the difference between grain used for bread production in a region and grain procured in the region (bread is not shipped over significant distances). Separating the credits for bread-making from those for grain procurement and distribution is a first step in understanding the regional pattern of grain credits.

Using the regional distribution of grain credit in 1992, one can estimate the average amount of credit associated with regional bread demand and the average amount of credit associated with procurement costs. Let $\mathrm{B}_{\mathrm{r}}$ represent bread consumption in region $\mathrm{r}$ in millions of kilograms. Such data can be calculated from population and regional bread consumption figures available from Goskomstat. Let $P C_{r}$ represent procurement costs in millions of rubles. $P C_{T}$ is equal to regional procurement volume times the average price per ton of grain in the region. ${ }^{29}$ Then a simple model of the distribution of grain credit $\mathrm{CR}_{\mathrm{r}}$ in millions of rubles across regions is

$$
\mathrm{CR}_{\mathrm{r}}=33.8+13.1 \mathrm{~B}_{\mathrm{r}}+1.23 \mathrm{PC}_{\mathrm{r}}+\mathrm{U}_{\mathrm{r}}, \mathrm{r}^{2}=.85, \sigma=3655
$$

where $U_{r}$ is the unexplained component of the regional grain credit. ${ }^{30}$

These results are interesting in several respects. They indicate that an additional kilogram of bread consumption in a region was associated with an additional 13.1 rubles of grain credit. In contrast, the procurement of an additional ruble worth of grain was associated with an additional 1.23 rubles of grain credit. These results suggest that about a third of total grain credit in 1992 went to support bread-making industries. ${ }^{31}$ The additional credit associated with grain 
procurement ( 0.23 rubles per ruble of grain procured) may have been to cover storage and distribution costs. These costs include the costs of interregional shipments of grain, which in 1992 had gross volume of 17.7 million tons and net volume 14.7 million tons. ${ }^{32}$ While the above model allows one to estimate some interesting parameters, in an economic sense it does not fit very well. The $\mathrm{r}^{2}$ for the model is relatively high because there are big differences in population and procurement volumes across regions, and these are correlated with the volume of credit allocated. However, the residual for the model amounts to $42 \%$ of the average credit disbursement among regions. Large differences in credits across regions remain unexplained by differences in regional bread consumption and regional procurement costs. ${ }^{33}$ For example, in Novgorodskiya oblast the amount of credit received was $332 \%$ higher than the above model can explain, while in Kaliningradskaya Oblast the amount of credit received was $\mathbf{8 1 \%}$ lower than the model indicates (see Table 7). The inability of Ministry of Finance officials to account for these differences illustrates the lack of oversight and monitoring of grain procurement credits. Anecdotal reports about the misuse of state credits provide further basis for concern. Most significantly, credit for grain procurement in 1993 was reduced dramatically without significant change in the volume and means of state procurement of grain, and without creating any disruptions in food supply. 
Table 7. Largest and Smallest Regional Recipients of Grain Credits in 1992 (in terms of the ratio of received credit to explained credit)

\begin{tabular}{|l|c|c|c|c|c|}
\hline \multicolumn{5}{|c|}{ Largest Credit Surpluses } \\
\hline region & $\begin{array}{c}\text { total } \\
\text { population } \\
\text { (ths.) }\end{array}$ & $\begin{array}{c}\text { grain } \\
\text { production } \\
\text { (ths. tons) }\end{array}$ & $\begin{array}{c}\text { grain } \\
\text { procurement } \\
\text { (ths. tons) }\end{array}$ & $\begin{array}{c}\text { grain credit } \\
\text { received } \\
\text { (mil Rb) }\end{array}$ & $\begin{array}{c}\text { unexplained } \\
\text { surplus/defici } \\
\text { t (\%) }\end{array}$ \\
\hline $\begin{array}{c}\text { Novgorodskiya } \\
\text { Oblast }\end{array}$ & 751 & 87 & 17.7 & 6550 & 332 \\
\hline $\begin{array}{c}\text { Sverdlovskaiya } \\
\text { Oblast }\end{array}$ & 4707 & 1015 & 5.2 & 23000 & 242 \\
\hline $\begin{array}{c}\text { Khabarovskii } \\
\text { Krai }\end{array}$ & 1812 & 22.2 & 0.5 & 6550 & 136 \\
\hline $\begin{array}{c}\text { Republic of } \\
\text { Khakasiya }\end{array}$ & 567 & 165.1 & 0 & 1670 & 98 \\
\hline $\begin{array}{c}\text { Amurskaya } \\
\text { Oblast }\end{array}$ & 1050 & 710.2 & 142.4 & 6940 & 91 \\
\hline $\begin{array}{c}\text { Kalingradskaya } \\
\text { Oblast }\end{array}$ & 871 & 359.1 & 20.5 & 300 & 81 \\
\hline $\begin{array}{c}\text { Moskovskaia } \\
\text { Oblast }\end{array}$ & 6646 & 613.7 & 39.7 & 1900 & 81 \\
\hline St. Petersburg & 4990 & 0 & 0 & 1815 & 73 \\
\hline $\begin{array}{c}\text { Permskaia } \\
\text { Oblast }\end{array}$ & 3091 & 910.4 & 90.5 & 1800 & 71 \\
\hline $\begin{array}{c}\text { Tomskaia } \\
\text { Oblast }\end{array}$ & 1001 & 420.7 & 44.8 & 830 & 69 \\
\hline
\end{tabular}

Source: Based on calculation from the above model. For more details, see Amelina, Galbi, Uspenskii (1993).

Ensuring that the population is able to purchase food is an important policy issue and one that is central to domestic economic and political security. The traditional Soviet approach to the problem is to provide massive state resources to organizations that in turn use the issue of state security to avoid public accountability in their use of state resources. The grain embargo imposed on the Soviet Union in 1980 undoubtedly played a key role in strengthening this approach with respect to grain. The appropriate path for reform is to decentralize and privatize state procurement functions. With respect to grain, the federal government's role in providing 
procurement credit needs to be reduced much further in order to stimulate the development of new marketing and distribution channels.

\section{Agricultural Input Subsidies}

While calls for agricultural subsidies have often referred to agriculture's "terms of trade" with industry, the path of relative prices is difficult to identify in the rapidly changing Russian economy. Since mid-1992 consumer food prices relative to non-food prices have been rising, although recently there has been some downward movement (see Figure 1). Moreover, agricultural wages appear to have grown more slowly than industrial wages. On the other hand, agricultural procurement prices have risen much less rapidly than consumer food prices, and the agricultural input price index and the industrial producer price index have risen more sharply than consumer food prices (see Table 8). 


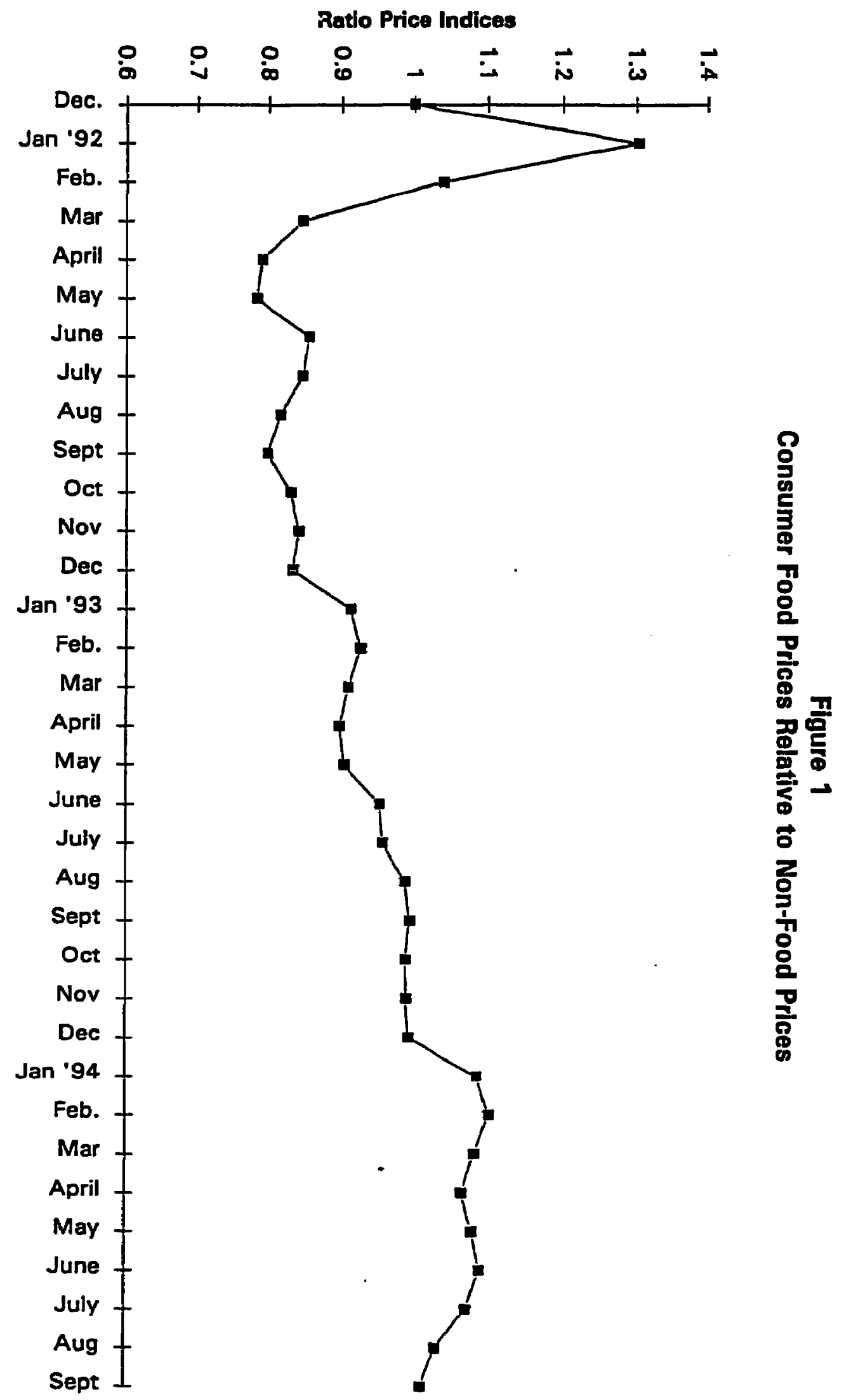


Table 8. Terms of Trade Indicators (index, relative to Dec. 1991)

\begin{tabular}{|l|c|c|c|}
\hline year & Dec. 1992 & Dec. 1993 & May 1994 \\
\hline $\begin{array}{c}\text { food consumer } \\
\text { prices }\end{array}$ & 22 & 197 & 315 \\
\hline $\begin{array}{c}\text { agricultural proc. } \\
\text { prices }\end{array}$ & 13 & 117 & 159 \\
\hline \begin{tabular}{c} 
agricultural wages \\
\hline $\begin{array}{c}\text { agricultural input } \\
\text { prices }\end{array}$
\end{tabular}$\quad 19$ & 219 & 124 \\
\hline $\begin{array}{c}\text { non-food consumer } \\
\text { prices }\end{array}$ & 27 & 199 & 292 \\
\hline $\begin{array}{c}\text { industrial wages } \\
\text { industrial producer } \\
\text { prices }\end{array}$ & 13 & 348 & 347 \\
\hline
\end{tabular}

Source: Goskomstat.

In interpreting these divergent trends, two points should be recognized. First, the ratio of food to non-food consumer prices is a significantly better quality statistic than the other statistics in Table 8. These two price indices are collected at the same time, in the same way, through direct surveys of prices observed in consumer markets. Wage statistics do not capture reductions in working time and late payment -- factors that have been significant throughout the economy. Moreover, the wage statistics and the input and industrial price indices are based on reports from enterprises, and hence are less reliable. Reporting meaningful prices for industrial intermediate goods is particularly problematic since markets for such goods are currently quite thin.

More importantly, agriculture's "terms of trade" is not a particularly relevant concept for thinking about the kinds of problems that are central to the current situation in Russian agriculture. Analyses of the "terms of trade" for agriculture tend to assume that there is a stable production function connecting inputs to outputs in the various sectors of the Russian economy. 
- But the essence of the transition problem is that reorganization of production potentially offers very great increases in productivity. The important questions are the extent to which such reorganization is happening, and how to promote it.

Concern about the terms of trade of agriculture seems to have been reflected in input cost subsidies for agriculture. In 1993, according to government decree, agricultural producers were compensated for $30 \%$ of the costs of mineral fertilizers and chemical pesticides, $50 \%$ of the cost of fuel used in agricultural production, $50 \%$ of the cost of drought insurance, and $50 \%$ of the cost of farm equipment and machinery. ${ }^{34}$ In 1994 the fuel subsidies was lowered to $30 \%$, while additional support was provided for the purchase of new agricultural machinery. ${ }^{35}$

Table 9. Agricultural Input Cost Subsidies (bln. of Rb)

\begin{tabular}{|l|l|l|l|}
\hline year & 1992 & 1993 & 1994 Fridgeted \\
\hline fuel & 70 & 13 & 8 \\
\hline fertilizer & 0 & 48 & 351 \\
\hline equipment & 5 & 23 & 24 \\
\hline insurance & 0 & 10 & 135 \\
\hline Other expenses & 76 & 35 & 285 \\
\hline $\begin{array}{l}\text { total as share of } \\
\text { GDP (\%) }\end{array}$ & 0.83 & 0.08 & 0.13 \\
\hline
\end{tabular}

Source: Freinkman (1994), Table 2.

From a budgetary perspective, input cost subsidies are not significant. In the 1994 budget input cost subsidies amount to only $6.7 \%$ of budgeted funds for agriculture. The explanation for the small role of input cost subsidies is not hard to recognize. Agricultural producers have frequently argued that input suppliers, rather than agricultural producers, have largely benefited from these subsidies. Agricultural producers have thus favored producer subsidies over input subsidies. 
While the overall volume of input subsidies has fallen, there has been a significant and undesirable shift in the composition of subsidies. The growth in fertilizer subsidies favors a particular type of rural activity and promotes a specialized industry likely to become dependent on the government program. Given the weaknesses of the state bureaucracy and the chaotic circumstances, the growth of insurance subsidies is likely to promote corruption and create significant unanticipated state liabilities.

An input subsidy program that can be effectively administered and that promotes rural development should subsidize a relatively standard commodity that is important in a wide variety of rural and non-rural activities. While input subsidies are in general an inefficient policy, fuel subsidies are probably the least bad form of input subsidy. Fuel subsidies encourage more broad-based development that other forms of input subsidies. They are also easier to administer and monitor, since, among other factors, fuel prices for non-agriculural users provide a benchmark for cost comparisons. Under the Soviet Union, energy prices were held far below . wo: $d$ levels. This encouraged inefficient, energy-intensive production throughout the economy. While allowing energy prices to rise to world levels is a crucial reform, this may also be a policy area where some marginal support can be given to rural development.

The regional distribution of fuel subsidies in 1992 is both more easily and better accounted for than the regional distribution of grain procurement credits in the same year. A regression of regional agricultural fuel subsidies in region $r\left(\mathrm{FS}_{\mathrm{r}}\right.$, in millions of rubles) on the use in agriculture of gasoline $\left(G_{r}\right.$, ths. tons) and diesel fuel $\left(D_{r}\right.$, ths. tons) in region $r$ produces the model: ${ }^{36}$ 


$$
\mathrm{FS}_{\mathrm{r}}=27+3.2 \mathrm{G}_{\mathrm{r}}+1.5 \mathrm{D}_{\mathrm{r}}+\mathrm{U}_{\mathrm{r}}, \mathrm{r}^{2}=.95, \sigma=125
$$

This model indicates that the subsidy per ton for gasoline and diesel fuel was $R b 3200$ and $R b$ 1500 respectively. The average wholesale prices of gas and diesel fuel in the second and third quarters of 1992 were $\mathrm{Rb} 5183$ and $\mathrm{Rb} 3950 .{ }^{37}$ Given the error bounds associated with the estimates, the model is consistent with a program of $50 \%$ subsidies for fuel use. In contrast to the model for grain credits, this model does not incorporate possible regional variations in fuel prices. Nonetheless, the model's $\mathrm{r}^{2}$ is higher than that for the grain credit model, and the standard error amounts to $17 \%$ of the mean regional subsidy, in contrast to $41 \%$ for the grain credit program. This indicates that there is much more reason to believe that fuel subsidies are being directed to their intended purpose than are grain procurement credits.

Developments in energy supply in the agricultural sector also suggest the importance of support in this area relative to other forms of agricultural support. In the first half of 1994 purchases of gasoline and diesel fuel through retailers fell $51 \%$ relative to the level of the first half of last year. In contrast, the procurement of gasoline through direct contacts with fuel producers increased sharply; such supplies were $64 \%$ higher for gasoline and $140 \%$ higher for diesel fuel in the first half of 1994 relative to the first half of $1993 .^{38}$ These direct deliveries probably reflect barter deals between large agricultural enterprises and fuel producers. Such trading mechanisms are inefficient, perpetuate the power of political connections, and place new agricultural organizations at a disadvantage. Temporary subsidies for rural fuel outlets could 
serve as a transitional mechanism that would help support market-based purchases of fuel while lowering the costs of a broad range of rural activities.

\section{V.Production Subsidies and Agricultural Adjustment}

A significant share of budgetary spending on agricultural falls under broad and vague programs for supporting agricultural production. In the 1994 budget $34 \%$ of spending on agricultural comes under a single line item allocating money "to finance expenses associated with resolving special problems in agricultural production." In 1993 and 1992 general support for agricultural producers was primarily through directed credits from the Central Bank. See Table 10. Such credits were issued in response to requests from producers. This is the traditional Soviet system in which the agricultural bosses petition the central authorities for money, plead their pressing needs, stress the importance of food to the people, and promise to produce results as soon as a sufficient amount of money is received. 
Table 10. General-Purpose Federal Transfers to Agricultural Producers (bln. Rb)

\begin{tabular}{|c|c|c|c|}
\hline year & $i 992$ & 1993 & 1994 budget \\
\hline $\begin{array}{l}\text { total general-purpose } \\
\text { transfers }\end{array}$ & 733 & 2155 & 5876 \\
\hline \multicolumn{4}{|l|}{ of which } \\
\hline livestock producers & 166 & 13 & 259 \\
\hline investment & $\overline{118}$ & 440 & 1500 \\
\hline directed credit & 417 & 1945 & $\mathbf{n} / \mathbf{a}$ \\
\hline $\begin{array}{l}\text { total general transfers as } \\
\text { share of GDP (\%) }\end{array}$ & 4.05 & 1.33 & 0.94 \\
\hline
\end{tabular}

While the generally ad-hoc nature of agricultural producer subsidies makes it virtually impossible to monitor their use and evaluate their effects, the program of support for livestock producers allows for slightly more detailed description and analysis. Funds for livestock subsidies come from both the federal and regional levels. As Table 11 indicates, subsidies as a percentage of procurement prices fell by about half from 1992 to $1993 .{ }^{39}$ In constant 1992 rubles, total livestock subsidies (federal and regional) fell from $\mathrm{Rb} 203$ billion to $\mathrm{Rb} 100$ billion from 1992 to 1993 . Within this overall fall there was a sharp shift in the source of subsidies. Federal subsidies, which in 1992 amounted to $82 \%$ of total livestock subsidies, became negligible in 1993 while regional subsidies increased three-fold in real terms. ${ }^{40}$ 
Table 11. Federal and Regional Livestock Subsidies

\begin{tabular}{|l|c|c|c|c|}
\hline & \multicolumn{2}{|c|}{$\begin{array}{c}\text { Total Volume } \\
\text { (bln. Rb) }\end{array}$} & \multicolumn{2}{c|}{$\begin{array}{c}\text { Subsidy relative to } \\
\text { procurement price (\%) }\end{array}$} \\
\hline year & 1992 & 1993 & 1992 & 1993 \\
\hline milk & 83.8 & 406 & 59 & 34 \\
\hline cattle & 50.5 & 224.2 & 66 & 25 \\
\hline pigs & 18.3 & 109.1 & 53 & 23 \\
\hline poultry & 22.6 & 108.7 & 62 & 21 \\
\hline eggs & 17 & 81.6 & 38 & 17 \\
\hline wool & 0 & 24.8 & 0 & 56 \\
\hline sheep & 5.2 & 13.9 & 182 & 33 \\
\hline
\end{tabular}

Source: Ministry of Agriculture (1994a).

There is already some evidence that the cut in federal livestock subsidies from 1992 to 1993 is promoting market-oriented adjustment. Regressing the 1992-1993 milk output change on the output growth trend 1986-1992 and the level of subsidies in 1992 indicates that relatively high subsidies in 1992 were correlated with a relatively large output falls from 1992 to $1993 .^{41}$ A movement from the first to the third quartile in the subsidy rate distribution in 1992 was associated with an additional one percentage point drop in output from 1992 to $1993 .^{42}$ This effect is large relative to the overall median regional output drop of $1.8 \% .^{43}$

An economic interpretation of this evidence is that subsidies were supportirg relatively costly production, and when these subsidies were cut such production fell. An important goal of federal agricultural policy should be to promote low-cost production and to encourage the transfer of resource from high-cost producers to more efficient uses. Cutting federal producer subsidies is an important step toward making production costs the key element of enterprise viability, and hence promoting efficient adjustment. 
However, the long-term effect of reducing federal producer subsidies depends on reactions at the local level. A significant effect of the reduction in federal subsidies was an increase (albeit less than offsetting) in regional subsidies, which in turn probably increased differences in the level of subsidization among regions. Such differences create incentives for agricultural producers in regions with a high rate of agricultural subsidization to use their cost advantage to capture markets in regions with a low rate of subsidization. The result of such action would be for regional agricultural subsidies to flow out of the region with the export of agricultural goods. This creates pressure on regional administrators either to restrict food exports or to lower subsidies. Regional administrators who restrict food exports create for themselves the opportunity to collect rents by granting particular exporters freedom of action. A regional leader with firm political control might even find it useful to raise agricultural subsidies." This could allow him to convert agricultural subsidies financed through general regional tax revenues into earnings for particular food trading concerns that served his personal interests. $^{45}$

Two political factors are central for avoiding this very bad outcome. First, regional democracy has to be strong enough to recognize and restrain the cost of agricultural subsidies. Second, the federal government has to preserve the rights of individuals to participate in interregional trade. This second task offers the federal government the possibility of creating significant, market-oriented alliances, and should be taken up as a central part of federal agricultural policy. 


\section{Conclusions}

Since the macroeconomic reforms of January 1992, agricultural reform in Russia has proceeded via a budgetary squeeze on traditional forms of agricultural support. This high-level budget cutting is clearly a crude way to shape agricultural policy. Yet alternative paths for policy face significant obstacles. Within the agricultural sector the strength of the culture of policy-making from the Soviet era is apparent in the forms of credit and subsidy programs. ${ }^{46}$ In addition, the administrative and regulatory capacity of the government has reached a very low level, and it is often not clear who are the ultimate recipients of agricultural credits and subsidies. ${ }^{47}$ The result is that the state and collective farms have had to orient themselves to markets because the state has become an unreliable, cash-strapped partner.

Proposals for new agricultural programs for the Russian government have often emphasized the need for the government to carry out its commitments and to concentrate resources on promising investment projects. ${ }^{48}$ While these objectives are desireable, they have little connection to reality. The traditional forms of agricultural policy that have been attempted in the past three years are not sustainable from a macroeconomic and budgetary perspective, hence the government could not credibly commit to them even if it wanted to. Moreover, the political time horizons of state organs are too short to induce them to allocate investment effectively even if they had experience in doing so, and there is little information available to judge the ability of particular organizations to carry out faithfully investment projects in the current environment. More political stability and further development of markets and private enterprise are needed for identifying and carrying out effective state investment. 
'In 1990 there was a general forgiveness of agricultural debt to the state, which amounted at that time to $\mathbf{R b} 20$ billion (equivalent to $3.1 \%$ of 1990 GDP). There have also been repeated rescheduling of the debts of Roskhleb, the state grain procurement agent. In addition, real interest rates on credits have often been very low. In 1993, a year in which inflation was about $850 \%$, a large share of agricultural credits were issued at interest rates of $10-25 \%$ yearly.

The amount assigned for enterprises and organizations of the agricultural complex was given as $\mathbf{1 8 . 1}$ trillion rubles. Lvestiga (1994)

${ }^{3}$ Total disbursement of $\mathrm{Rb} .8 .3 \mathrm{tr}$. Ibid.

The allocation for agricultural research was Rb 381 bln. See Budget RF (1994). A rough mid-year exchange rate of $3000 \mathrm{Rb} / \$$ was used for the reported figure.

${ }^{S}$ See Hedlund (1989).

6Banks also participated as decision-makers in the process of allocating directed credits to private farmers. Farmers claimed that banks refused to issue credits allocated to them, while banks argued that they were withholding credit because they were not receiving interest rate subsidies promised to them. The extent to which the central bank actually forced semi-commercial banks to pay the full central bank rate on directed credits to private farmers is not clear. The nature and securitization of "guarantees" that banks required from AKKOR and/or the Russian Farmer Fund (an AKKOR affiliate) in order to give farmers credit is also not clear. See Kiselev (1994), pp. 78-9, esp. Table 4 and 5.

'Information received via personal communication with the Russian Farmer Fund, Moscow.

Goskomstat (1993a) p. 5.

'See Brooks and Lerman (1994).

${ }^{10}$ However, at the local level complaints about comption and inequities in the allocation of state support were frequent.

"Quoted in Wegren (1994) p. 226

${ }^{12}$ It is worth noting that a survey of private farmers found that only about $30 \%$ of parcels were allocated directly from state or collective farms. See Brooks and Lerman, p. 57. 
${ }^{13}$ Goskomstat (1994), p. 45.

"One might expect that private farmers would receive at least the state credit directed to them. On the other hand, there have been frequent reports of state agricultural credits being put to use outside agriculture.

${ }^{15}$ There is also evidence of the importance of private agricultural credit in China. A small amount of Chinese evidence shows that private credit in agriculture is about twice as large as the sum of that from the state agricultural bank and agricultural credit cooperatives. Lin (1987).

${ }^{16}$ Goskomstat (1993a) p. 5, (1994a) p. 14.

${ }^{17}$ See Prosterman and Hanstad (1993).

${ }^{13}$ Others have reached the same conclusion. Kiselev, a scholar in the Agrarian Institute in Moscow, noted, "When we evaluate the system of state suport for peasant farms, we can say that in many respects it preserves the character of regulation that is characteristic of a statized economy." See Kiselev (1994) p. 80.

${ }^{19}$ Food Decree RF (1994).

${ }^{20}$ See Freinkman and Titov (1994), p. 12.

${ }^{21}$ See Rossiya - 1994 (1994) Graph VI.6, p. 168.

${ }^{22}$ Central Bank statistics show Rb 1797 bln. credits rescheduled in the agricultural sector in 1993, while Freinkman (1994), Table 2, indicates that $\mathrm{Rb} 4385$ were bln. disbursed.

${ }^{20}$ Pavlovsky (1968).

${ }^{24}$ This company is explicitly named in the ffederal decree. See for example Food Decree RF (1994). In earlier years Roskhleb was also responsible for regional procurement.

${ }^{25}$ The following section draws on ideas from Afanasev, Aslund, and Galbi (1993).

${ }^{26} A$ simple example helps illustrate the point. Suppose that the domestic supply curve facing the state is $k_{d} S_{d} e_{d}=P_{d}$ and the international supply curve is $\mathrm{k}_{\mathbf{i}} \mathrm{S}_{\mathbf{j}} \mathrm{e}_{\mathrm{i}}=\mathrm{P}_{\mathbf{j}}$. Then a cost-minimizing procurement program involving both domestic and international purchases would entail a ratio of international to domestic prices of $\mathbf{P}_{\mathbf{i}} / \mathbf{P}_{\mathbf{d}}=$ $\left(1+e_{d}\right) /\left(1+e_{j}\right)$. Suppose that Russia could buy as much grain as it wants on the world market without effecting the world price; this implies that $e_{i}=0$. Suppose that domestically, in order to procure $10 \%$ more grain, the government 
has to offer agricultural producers a $10 \%$ higher price; this means that $e_{d}=1$. Thus in the cost-minimizing procurement program grain will be procured internationally at twice the price of domestic grain.

${ }^{27}$ One could argue that the independence between the variations in imports and the variations in the size of the harvest might reflect stockpiling in response to international price fluctuations. Particularly in the 1980 's, this is unlikely given hard-currency government budget constraints.

${ }^{28}$ The following material on grain procurement credits draws upon Amelina, Galbi, and Uspenskii (1993).

${ }^{29}$ The interquartile range in the distribution of regional procurement prices was equal to $32 \%$ of the median regional procurement price.

${ }^{30}$ The number of regions that received grain credits is 71 . This includes all the major regions of the Russian Federation. The model sample consists of these regions, minus Arkhangelskaia Oblast ( $R b 600$ mln. credit), Republic of Karachaevo-Cherkesiya (Rb $200 \mathrm{mln}$. credit), Sakhalinskaiya Oblast (Rb $4000 \mathrm{mln}$. credit), and the Jewish Autonomous Oblast (Rb $2170 \mathrm{mln}$. credit). Procurement yolume or price data for these regions were missing.

${ }^{31}$ There are about 150 million persons in Russia, and average bread consumptions is about $120 \mathrm{~kg}$ per year. Hence the model suggest that credits for bread-making were about $\mathrm{Rb} 244$ billion.

${ }^{32}$ The volume of grain shipments to a particular region does not significantly affect the volume of credit received by the region. This is not surprising. Why should Roskhleb need additional net credit from the state in order to allow one branch of Roskhleb to buy grain from another branch?

${ }^{33}$ These differences cannot reflect movements in prices during the year, since actual oblast level procurement costs were used in the analysis.

${ }^{34}$ Input subsidy ref.

${ }^{35}$ Food Decree RF (1994).

${ }^{36}$ The number of regions used in estimating the model is 72 . These are all the regions for which subsidy data was available, and include all the major regions of the Russian Federation.

${ }^{37}$ OECD (1994). 
${ }^{38}$ Goskomstat (1994b), p. 43.

${ }^{39}$ Livestock subsidies are supposed to be paid only for products delivered to the state. However, in the 1992 regional cross-section the subsidy rate per unit of milk and meat production is not significantly correlated with the share of milk and meat sold to the state. There is a positive correlation for eggs.

${ }^{40}$ In 1993 federal livestock subsidies amounted to $1.3 \%$ of total livestock subsidies.

"' Data from Ministry of Agriculture (1993b), (1994b).

${ }^{12}$ The coefficient of the logarithm of the regional milk subsidy rate was -.050 with a standard error of .015 . The sample for the regression was the 72 regions of Russia for which data was available (see above).

${ }^{43}$ This effect is not detectable for eggs, perbaps because the subsidy rate is significantly lower and the magnitude of the output drops higher. This suggests that factors other than subsidies are driving adjustments in egg production. I did not have data on meat output separated into cattle, pigs, and poultry for a similar analysis with respect to these products.

${ }^{\text {th }}$ The elasticity of subsidies with respect to regional fiscal expenditure (controlling for the volume of procurement) is statistically significant and around 0.5 . The share of a region's population in agriculture also has a significant effect on the subsidy rate. The political economy of regional agricultural subsidies in Russia deserves further exploration.

ts I am grateful to Lev Freinkman for pointing out this possibility to me.

${ }^{46}$ For a discussion and example of the importance of the culture of policy-making, see Murrell, Dunn, and Korsun (1994).

${ }^{47}$ See Izvestiya (1994).

48 Ibid. 


\section{Bibliography}

Afanasev, Mstislav, Anders Aslund, and Douglas Galbi (1993), "Grain Prices and Procurement Policy", Macroeconomic and Finance Unit, August, Moscow. Amelina, Maria, Douglas Galbi, and Andrei Uspenskii (1993), "The Distribution of Central Bank Credits for Grain Procurement", Macroeconomic and Finance Unit, September, Moscow.

Brooks, Karen, and Zvi Lerman (1994), Land Reform and Farm Restructuring in Russia, World Bank Discussion Paper 233, Washington.

Budget RF (1994), "Federal'nyi Zakon o federal'nom dyudzhete na 1994 god", Rossiiskie Vesti, No. 123 (547) July 6, 1994, p. 4.

Center for Economic Affairs (1994), Rossiya - 1994, Ekonomicheskaya Kon'yunktura, Bypusk 2, Moscow.

Food Decree RF (1993), "Sovet Ministrov -- Provitel'stvo Rossiiskoi Federatsii, Postanovlenie ot 22 Fevralya 1993 g. No. 155, o formirovanii federal'. $\mathrm{kkh}$ i regional'nyx prodovol'stvennykh fondov v 1993 gody", Moscow.

Food Decree RF (1994), "Sovet Ministrov - Provitel'stvo Rossiiskoi Federatsii, ot 23 Fevralya 1994 g. No. 126 ob ekonomicheskikh usloviyax funktsionirovaniya agropromyshlennogo kompleksa Rossiiskoi Federatsii v 1994 gody", Moscow. 
Freinkman, Lev (1994), "Government Financial Transfers to the Enterprise Sector in Russia", paper presented at the IIASA Conference on Russian Output Trends, June 11-18, Vienna.

Freinkman, Lev, and Stepan Titov (1994), The Transformation of the Regional Fiscsal System in Russia: The Case of Yaroslovl, World Bank Internal Discussion Paper 143, Washington.

Goskomstat Rossii (1994a), Itogi Khozyastvennoi Deyatel'nocti Krect'yanshylkh (Fermerskykh) Khozyaistv Possiiskoi Federatsii v 1993 gody, Moscow.

Goskomstat Rossii (1994b), Sotsial'no-ekonomicheskoe Polozhenie Rossii, Yanvar'-Iyrun' 1994, Moscow.

Goskomstat Rossii (1993a), Krest'yanskie (Fermerskie) Khozyastva Rossiickoi Federatsii (po dannim obsledovaniya na 1 yanvarya 1993 goda), Moscow.

Hedlund, Stefan (1989), Private Agriculture in the Soviet Union, New York: Routledge. Izvestiya (1994a), "Trilliony dlya sela: kuda? komu? zachem?", three part series, November 22-24, 1994.

Kiselev, Sergei (1994), "The State and the Farmer", in Problems of Economic Transition, Vol. 36, No. 10 (February).

Lin, Justin Yifu (1987), "Rural Factor Markets in China After the Household Responsibility System Reform", Yale Economic Gronth Center Discussion Paper 535, April.

Ministry of Agriculture RF (1994a), "Raschet izmeneniya rezul'tatov ot realizatsii cel'khozyastvennoi produktsii v 1993 gody v gosresursy", Moscow. 
Ministry of Agriculture RF (1994b), Statisticheskii Byulleten Osnovmykh Pokazatelei Agrarnogo Kompleksa, preliminary data, Moscow.

Ministry of Agriculture RF (1993a), Statisticheskii Byulleten' No. I AP Osnovnykh Pokazatelei Funktsionirovanii Agrarnogo Kompleksa, Moscow. Ministry of Agriculture RF (1993b), Sbornik Pokazatelei Realisatsii Sel'skokhozyaistvennoi Produktsii za 1988-1992 g.g., Moscow.

Murrell, Peter, Karen Tumer Dunn, and Georges Korsun (1994), "The Culture of PolicyMaking in the Transition from Socialism: Prce Policy in Mongolia", paper presented at the conference Economic and Political Institutions for Sustainable Development: Implications for Assistance, October 24-25, Washington. OECD (1994), International Energy Agency, Russian Energy Prices, Toxes and Costs, Paris.

Pavlovsky, George (1968), Agricultural Russia on the Eve of the Revolution, New York. Prosterman, Roy L., and Timothy Hanstad (1993), "A Fieldwork-Based Appraisal of Individual Peasant Farming in Russia", in Don Van Atta, ed., The "Farmer Threat", Westview Press: Boulder, Colorado.

Wegren, Stephen K. (1994), "Rural Reform and Political Culture in Russia", Europe-Asia Studies, Vol. 46, No. 2. 
Tite

WPS1425 On the Intersectoral Migration of Agricultural Labor

WPS1426 Russian Unemployment: Its Magnitude, Characteristics, and Regional Dimensions

WPS1427 Corporate Governance and Equity Prices: Evidence from the Czech and Slovak Republics

WPS1428 Short-Term Supply Response to a Devaluation: A Model's Implications for Primary Commodity-Exporting Developing Countries

WPS1429 The World Trade Organization's Agreement on Government Procurement: Expanding Disciplines, Declining Membership?

WP51430 Intergovernmental Fiscal Relations and Poverty Alleviation in Viet Nam

WPS1431 The Industrial Pollution Projection System

WPS1432 Using Financial Futures in Trading and Risk Management

WPS1433 Enterprise Restructuring in Eastem Europe: How Much? How Fast? Where? Preliminary Evidence from Trade Data

WPS1434 Govemment Credit Policy and Industrial Performance (Japanese Machine Tool Procucers, 1963-91)

WPS1435 The Political Economy of Formal Sector Pay and Employment in Developing Countries

WPS1430 An Empirical Model of Sunk Costs and the Decision to Export
Author

Donald Larson

Yair Mundlak

Simon Commander

Ruslan Yemisov

Stijn Claessens

Bruno Boccara

Fabien Nsengiyumva

Bemard M. Hookman

Petros C. Mavroidis

Richard M. Bird Jennie I. Litvack

M. Govinda Rao

Hemamala Heltige

Paul Martin

Manjula Singh

David Wheeler

Ignacio Mas

Jesús Saá-Requejo

Bemard Hnekman

Gerhard Pohl

Charles W. Calomiris

Charles P. Himmelberg

Arup Baneri

J. Edgardo Campos

Richard H. Sabot

Mark J. Roberts

James R. Tybout
March 1995

Date

February 1995

Fobruary 1995

February 1995

February 1995

March 1995

March 1995

March 1995

March 1995

March 1995

March 1995

D. Evans

37496

March 1995

J. Ngaine 37959
34963

F. Hatab 38535

G. Coward 80494

A. Williams 37176

K. Binkley 81143

F. Hatab 35835

P. Infante 37642 


\begin{tabular}{|c|c|c|c|c|}
\hline & Thle & Author & Date & $\begin{array}{l}\text { Contact } \\
\text { for paper }\end{array}$ \\
\hline WPS1437 & $\begin{array}{l}\text { Travel Mode Substhution in Săo } \\
\text { Paulo: Estimates and Implications } \\
\text { for Air Pollution Contrcl }\end{array}$ & $\begin{array}{l}\text { Joftre Swalt } \\
\text { Gunnar S. Eskeland }\end{array}$ & March 1995 & $\begin{array}{l}\text { C. Jones } \\
37699\end{array}$ \\
\hline WPS1438 & Trade Peform, Efficiency, and Growth & $\begin{array}{l}\text { Ejaz Ghani } \\
\text { Cart Jayarajah }\end{array}$ & March 1995 & $\begin{array}{l}\text { A. Nokhostin } \\
34150\end{array}$ \\
\hline WPS1439 & $\begin{array}{l}\text { Nontariff Barriers Africa Faces: What } \\
\text { Did the Uruguay Round Accomplish, } \\
\text { and What Remains to Be Done? }\end{array}$ & $\begin{array}{l}\text { Azita Amjadi } \\
\text { Alexander Yeats }\end{array}$ & March 1995 & $\begin{array}{l}\text { S. Lipscomb } \\
\mathbf{3 3 7 1 8}\end{array}$ \\
\hline WPS1440 & $\begin{array}{l}\text { Poverty and Social Transfers in } \\
\text { Poland }\end{array}$ & Christiaan Grootaen & March 1995 & $\begin{array}{l}\text { N. Sachdeva } \\
82717\end{array}$ \\
\hline WPS1441 & $\begin{array}{l}\text { The Significance of Credits and } \\
\text { Subsidies in Russian Agricultural } \\
\text { Reform }\end{array}$ & Douglas Galbi & March 1995 & $\begin{array}{l}\text { N. Castillo } \\
33490\end{array}$ \\
\hline WPS1442 & $\begin{array}{l}\text { Energy Price Increases in } \\
\text { Developing Countries: Case Studies } \\
\text { of Colombia, Ghana, Indonesia, } \\
\text { Malaysia, Turkey, and Zimbabwe }\end{array}$ & $\begin{array}{l}\text { Einar Hope } \\
\text { Balbir Singh }\end{array}$ & March 1995 & $\begin{array}{l}\text { C. .lones } \\
37699\end{array}$ \\
\hline
\end{tabular}


